\title{
ZOONOTIC HEALTH HAZARDS CONCERNING BRUCELLOSIS AND LEPTOSPIROSIS IN EGYPTIAN SWINE AND HUMAN IN CONTACT
}

\author{
A.M.A. BARAKAT ${ }^{*}$; E.R.H. ATTIA ${ }^{* *}$ and SYLVIA O. AHMED ${ }^{* * *}$ \\ * Zoonotic Diseases Department, National Research Center, Giza, Egypt. \\ ** Mastitis \& Neonates Diseases Department, Leptospirosis Unite, Animal Reproduction Research Institute (ARRI), Haram, \\ Giza, Egypt. \\ *** Department of Animal Hygiene and Zoonosis, Faculty of Veterinary Medicine, Assuit University, Egypt.
}

\section{ABSTRACT}

Received at: 26/6/2012

Accepted: 2/8/2012
Brucellosis and Leptospirosis are the most symbolistic swine occupational bacterial zoonosis constitutes direct occupational hazards for manipulating employees or animals that licked or eaten the aborted fluid or membranes. Occupational workers appear to be the most risk groups of contracting the diseases from pigs. It's of ecological impact and on target zoonosis to detect the sero-prevalence of those two zoonosis in human in contact with free living swine, reflect the human bio-hazards are due to direct contact with contaminant swine subset. Pigs are naturally exposed to zoonotic agents in their subset with subsequent direct occupational human hazards. Brucella and Leptospira are infectious agents probably reflects a major bacterial hazards for human in contact with the free living swine in addition the economical drawbacks consequences to swine abortion and piglet depletion. A total of 250 free rearing pigs blood samples were collected from different localities in large Cairo governorate, Egypt. Also, 150 serum samples were collected from occupational workers. Human and swine sera were tested for antibodies against the two zoonotic diseases by using Egyptian locally serological antigens and commercial kits. Antibodies against Brucella were detected in $42 \%$ of 250 pig samples using RBPT. The most sensitive confirmatory test was SAT 37.6\%.The seropositive percent of human in contact using SAT 4.7\%. Antibodies against three Leptospira serovars were detected in $66.8 \%$ of the serum samples from pigs using the Microscopic Agglutination Test (MAT) at titers of $1 \geq 200$. The highest seroprevalence was recorded for L. Pomona serovar $32.4 \%$ followed by L. grippotyphosa $20.8 \%$ and then the lowest prevalence detected by L.icterohaemorrhagiae $13.6 \%$. While in human $25.3 \%$ were positive with the highest incidence corresponding to L. Pomona $11.3 \%$.

Key words: Zoonotic Health hazard, swine, Brucellosis, Leptospirosis.

\section{INTRODUCTION}

More than 30 diseases are considered common to man and pig. Most of them, such as salmonellosis, trichinellosis, toxoplasmosis, Q fever, leptospirosis etc. may involve other animal species as well, while others are specifically porcine-related, such as Taenia solium (the cestode causing human cysticercosis), Streptococcus suis and Brucella suis (Shimshony, 2009). Brucellosis is one of the most important bacterial zoonosis worldwide (Young, 1995). The alarm toward Brucellosis that is highly contagious disease have Egyptian authorities priority, it's an endemic disease among Egyptian humans and animals (WHO, 1998).
Laboratory testing is an absolute prerequisite for a proper diagnosis of human brucellosis and for detection and confirmation of brucellosis in animals. Laboratory diagnosis of brucellosis in animals or man may be achieved either through blood culture or serological testing (Smits and Culter, 2004).

Poor reproducibility has been demonstrated with a frequently used serological screening test, the Rose Bengal test (RB), when performed at different study sites (Maichomo et al., 1998). Specificity issues have also plagued the (RB) test. Consequently, positives should be confirmed in a more specific test such as the serum agglutination test, complement fixation test, or the enzyme linked immunosorbent assay (Omer et al., 2002; Al Dahouk et al., 2003). 
Leptospirosis has been recognized as an emerging global public health problem because of its increasing incidence in both developing and developed countries (Slack et al., 2008).

Leptospirosis is considered as one of the most widespread zoonoses worldwide (Levett, 2001). The disease is caused by spirochetes of the genus Leptospira, Most of leptospira serovars can infect different animal species, but there genus is a primary host reservoir for each serovar, which ensures the survival and dissemination of the organisms (Birnbaum et al., 1998).

The standard method for serological diagnosis of leptospirosis is the microscopic agglutination test (MAT), usually with a cut-off value at 100 (Faine et al., 1999). To the cut-off value at 100, the MAT sensitivity is belived to be only moderate (Mousing et al., 1995) and infected animals may have titers below the widely accepted minimum significant titer of 100, but the specificity is good (Ellis, 1999).

The economic loses and zoonotic potential of leptospiral infections in pigs are recognized throughout the world. The most commonly incriminated serovars are Pomona and tarassoni (Hathaway and little, 1981). Pigs of all ages are susceptible to Leptospirosis. Death or retarded development may occur in young pigs. Abortion and stillbirth are also consequences of infections (Faine, 1994).

For the pervious reasons this study done for throw the focus on Bacterial zoonotic diseases infect human in contacts with swine as Leptospirosis \& Brucellosis in cairo, Egypt.

\section{MATERIALS and METHODS}

A total of 250 blood samples were collected from free rearing pigs from different herds scattered at Cairo, Giza \& Qalyobia Provinces. Also, 150 blood samples were collected from human in contact.

Samples were centrifuged within 24 hours from collections and sera were collected. Serum of each sample was numbered, divided into 2 obliquities and stored at $-20^{\circ} \mathrm{C}$ until tested. Sera were tested at the Department of Zoonotic Diseases National Research Centre, Dokki, Giza, Egypt and Leptospirosis Unite belonging to Department of Mastitis \& Neonates Diseases at Animal Reproduction Research Institute, Haram, Giza, Egypt.

Human and swine sera were tested for antibodies against the two zoonotic diseases. the test methods and antigen types used were given in the following table

Table 1: Test method and Antigen types

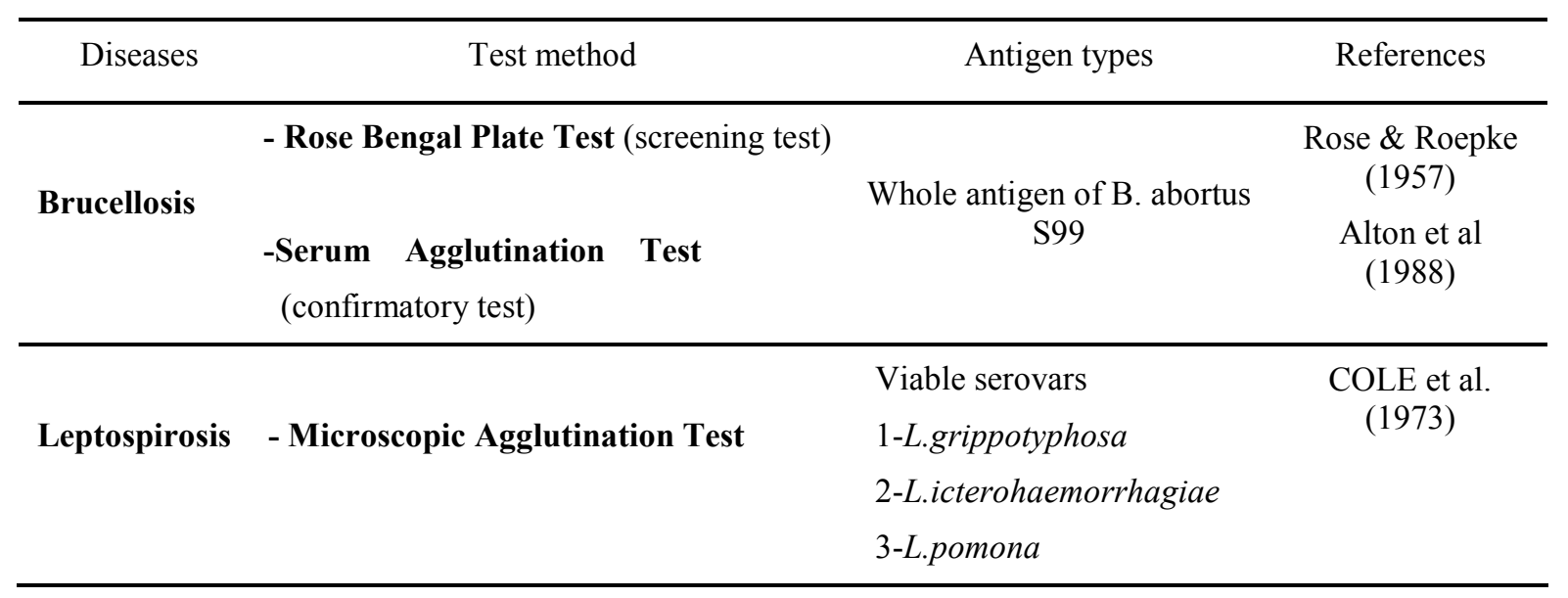

\section{A- Serology of Brucellosis in pigs \&human sera:}

- Rose Bengal plate Test (RBPT):

The Rose Bengal stained Brucella antigen is used for the early detection of Brucella agglutinins (Brucella abortus, melitensis and suis) according to Rose and Roepke (1957).

- Serum Agglutination Test (SAT):

The most widely used test and was performed as described by Alton et al. (1988)

\section{B- Serology of Leptospirosis in pigs \&human sera:}

- Microscopic Agglutination Test (MAT):

Improved microtechnique for detection of leptospira antibodies, which Performed as described by Cole et al. (1973). 


\section{RESULTS}

Table 2: Seroprevalence of Brucellosis and Leptospirosis in Human and pig sera:

\begin{tabular}{|c|c|c|c|c|c|c|}
\hline & $\begin{array}{c}\text { No of } \\
\text { tested } \\
\text { Pig sera }\end{array}$ & $\begin{array}{c}\text { NO of } \\
\text { seropositive } \\
\text { tested samples }\end{array}$ & $\begin{array}{c}\text { Seropositive } \\
\%\end{array}$ & $\begin{array}{l}\text { No of tested } \\
\text { Human sera }\end{array}$ & $\begin{array}{c}\text { NO of } \\
\text { seropositive } \\
\text { tested } \\
\text { samples }\end{array}$ & Seropositive $\%$ \\
\hline \multirow{2}{*}{$\begin{array}{l}\text { Brucella } \\
\text { spps }\end{array}$} & \multirow{3}{*}{250} & 105 (RBPT) & $42 \%$ & \multirow{3}{*}{150} & $9(\mathrm{RBPT})$ & $6 \%$ \\
\hline & & 94 (SAT) & $37.6 \%$ & & 7 (SAT) & $4.7 \%$ \\
\hline $\begin{array}{l}\text { Leptospira } \\
\text { spps }\end{array}$ & & 167 (MAT) & $66.8 \%$ & & 38 (MAT) & $25.3 \%$ \\
\hline
\end{tabular}

RBPT $=$ Rose Bengal Plate Test

$\mathrm{SAT}=$ serum agglutination test

MAT $=$ Microscopic Agglutination Test.

Table 3: Detection of leptospira serovars antibodies in pigs sera using Microscopic Agglutination Test:

\begin{tabular}{lccccccc}
\hline \multirow{2}{*}{ serovars } & \multicolumn{2}{c}{250 tested pigs } & \multicolumn{5}{c}{$1 \geq 200$ MAT Titers (total immunoglobulin) } \\
\cline { 2 - 8 } & Seropositive & $\%$ & $1 / 200$ & $1 / 400$ & $1 / 800$ & $1 / 1600$ & $1 / 3200$ \\
\hline L.pomona & 81 & 32.4 & 9 & 16 & 21 & 27 & 8 \\
\hline L.icterohaemorrahgiae & 34 & 13.6 & 4 & 7 & 9 & 11 & 3 \\
\hline L.grippotyphosa & 52 & 20.8 & 8 & 12 & 16 & 9 & 7 \\
\hline Total & 167 & 66.8 & & & & & \\
\hline
\end{tabular}

Table (3) summarizes the results obtained by Microscopic Agglutination Test, it was noticed that leptospiral agglutinins against three leptospiral serovars were detected in 167 out of 250 pig sera (66.8\%); meanwhile, L. pomona antibodies was the most predominant in pig sera with $(32.4 \%)$ of the total number of the examined sera followed by L.grippotyphosa (20.8\%) and then L.icterohaemorrhagiae (13.6\%).

Table 4: Detection of leptospira antibodies in human sera using Microscopic Agglutination Test:

\begin{tabular}{lccccccc}
\hline \multirow{2}{*}{ serovars } & \multicolumn{2}{c}{150 tested persons } & \multicolumn{2}{c}{$1 \geq 200$ MAT Titers (total immunoglobulin) } \\
\cline { 2 - 8 } & Seropositive & $\%$ & $1 / 200$ & $1 / 400$ & $1 / 800$ & $1 / 1600$ & $1 / 3200$ \\
\hline L.pomona & 17 & 11.3 & 2 & 4 & 4 & 6 & 1 \\
\hline L.icterohaemorrahgiae & 10 & 6.7 & 4 & 2 & 1 & 3 & 0 \\
\hline L.grippotyphosa & 11 & 7.3 & 3 & 4 & 2 & 2 & 0 \\
\hline Total & 38 & 25.3 & & & & & \\
\hline
\end{tabular}

Table (4) summarizes the results obtained by Microscopic Agglutination Test, it was noticed that leptospiral agglutinins against three leptospiral serovars were detected in 38 out of 150 human sera (25.3\%); meanwhile, L.Pomona antibodies was the most predominant in human sera with $(11.3 \%)$ of the total number of the examined sera followed by L.grippotyphosa $(7.3 \%)$ then L.icterohaemorrahgiae $(6.7 \%)$. 
$\underline{\text { Assiut Vet. Med. J. Vol. } 58 \text { No. } 134 \text { July } 2012}$

Table 5: Detection of Brucella antibodies in pig sera using Rose Bengal Plate Test:

\begin{tabular}{ccc}
\hline \multicolumn{3}{c}{250 tested pigs } \\
\\
\hline Brucella SPP & Seropositive & $\%$ \\
\hline Brovars & 105 & 42 \\
\hline
\end{tabular}

Table 6: Detection of Brucella antibodies in pig sera using Serum Agglutination Test:

\begin{tabular}{ccccc}
\hline Serovars & \multicolumn{4}{c}{250 tested pigs } \\
\hline & Seropositive & $\%$ & $1 / 160$ & $1 / 320$ \\
\hline Brucella SPP & 94 & 37.6 & 50 & 44 \\
\hline
\end{tabular}

Table 7: Detection of Brucella antibodies in human sera using Rose Bengal Plate Test:

\begin{tabular}{ccc}
\hline Serovars & 150 tested persons & \\
& Seropositive & $\%$ \\
\hline Brucella SPP & 9 & 6 \\
\hline
\end{tabular}

Table 8: Detection of Brucella antibodies in human sera using Serum Agglutination Test:

\begin{tabular}{ccccc}
\hline Serovars & \multicolumn{4}{c}{150 tested human sera } \\
\hline & Seropositive & $\%$ & $1 / 160$ & $1 / 320$ \\
\hline Brucella SPP & 7 & 4.7 & 5 & 2 \\
\hline
\end{tabular}

Antibodies against Brucella were detected in 105 (42\%) of 250 pig samples using RBPT. The most sensitive confirmatory test was SAT 94 (37.6\%). The seropositive percent of human in contact 7(4.7\%).

\section{DISCUSSION}

Pigs included in this study appeared to be in good health when blood samples were taken; perhaps confirming the belief that, in pigs, equilibrium exists between the diseases agents and the host, but serologically there is evidence of zoonotic disease agent antibody activity. Serologic procedures to detect antibodies against Brucella in infected pigs are the most practical and most common means of diagnosis. Apparent healthy seropositive swine may be chronic shedders for Brucella and Leptospira via urine and other body fluids. Leptospirosis has been known as a zoonotic disease, caused by pathogenic spirochetes of the genus Leptospira. Zakład Chorób Swiń (2011).

In the present study a combination of Rose Bengal Plate Test and Serum Agglutination Test appeared to be advantageous in detecting individual reacting pigs, Brucella antibodies were found in $37.6 \%$ of the pigs tested, probably reflecting high prevalence of infection. This finding is in full agreement with results obtained by Zaki (1948) on Brucella infection in pigs in large breeding establishment in upper Egypt.

The discrepancy between the high reactors detected by RBPT in Tables $(5 \& 7)$ than the results obtained by SAT in Tables (6\&8)may be due to the fact that it is a highly sensitive test, which can detect low titer as in case of chronic brucellosis that can not be considered positive by the quantitative tests (Nicolett, 1982). On the other hand, Serum Agglutination Test is 10 times more sensitive to IgM than IgG1 and IgG2 antibodies (Alton et al., 1988).

In this study, $37.6 \%$ and $4.7 \%$ of the examined swine and contact persons sera of Serum Agglutination Test had Brucella antibodies respectively, the compatibility between swine and human percentages are due to the fact that Brucella is of highly contagious characters. Where humans in contact mainly contracted infection from shedder swine, and usually predisposes farmers, shepherds, butchers, laboratory workers, veterinarians 
and slaughterhouse workers. Also, indicate that swine behavior in clay water pools may play vital role for swine and human communication via droplet infection and through intact or abraded skin. Of 80 veterinarians, $92 \cdot 5 \%$ had serological evidence of past or present Brucella infection (Pappas et al., 2006). Also, lower results of brucella antibodies in human were recorded by Omer et al. (2002) who found that the prevalence of brucellosis among high risk occupational groups using Rose Bengal test is among occupational personnel (4.5\%). Mudaliar et al. (2003) recorded prevalence of brucellosis of $5.33 \%$ in animal handlers and advised that the clinician should keep in mind the possibility of an occupational or environmental exposure in cases of fever of unknown origin.

Human brucellosis seroprevalence of $3.8 \%$ has been reported from Chad (Schelling et al., 2003), 13.3\% in Uganda (Mutanda, 1998) and in eastern Nigeria a 5.2\% were seropositive (Baba et al., 2001).

Leptospirosis, a worldwide distributed zoononis caused by bacteria of the genus Leptospira (antigenically classified into serovars), may be directly or indirectly transmitted through infected urine or environment.Several domestic and wild animals are leptospirosis reservoirs. The disease presents occupational character since it is widely reported in professionals that work in humid environments. In developing countries, outbreaks are related to lack of sanitation, overcrowding in inadequate housing and climatic conditions.Leptospirosis causes numerous public health problems and educational activities are very important to its control (Ullmann and Langoni, 2011).

Leptospirosis affects professionals that are constantly in contact with animals and their residues, especially reservoirs (Tiwari, 2008).

Concerning leptospirosis, in this study, the percent of infected swine and contact humans are compatible $66.8 \%$ and $25.3 \%$, respectively. The higher incidence in workers may be clarified due to the fast changeability in swine herd individuals, in contrast to long term stability with the same occupational employees.

The report of Burriel et al. (2003) in Greek swine herds indicated a prevalence rate for leptospira interrogans serovars $(28.2 \%)$ a figure which is lower than that given in the present study. Among the serovars reported in other countries, serovar Pomona is the most important in pigs (Faine et al., 1999; De lang et al., 1987; Van Til and Dohoo, 1991), agreeing with the present work. It has been suggested that swine are important maintenance host for serovar Pomona (Faine et al., 1999).

In the present study leptospirosis seroprevalence in human samples were $25.3 \%$ the result was in agreement with the study found in Israeli Troops near Jordan River (Hadad et al., 2006). On the other hand the seroprevalence was $9.5 \%$ in slaughter workers in New Zealand (Benschop et al., 2009).

In the present study, the rectant serovars and respective frequencies were L. icterohaemorrhagiae (13.6\%) and L. grippotyphosa (20.8\%) a figure which is higher than reported by DE. AZEVEDO et al. (2008), who found that seropositivity for L. icterohaemorrhagiae $(9.5 \%)$ and L. grippotyphosa (4.8\%).

Infected sows may be aborted consequence to infection by Brucella and Leptospira while their foeti, fetal fluid, and membranes are harboring the causative pathogen. So, the aborted swine constitute direct occupational health hazard for manipulating employees.

Apparent healthy seropositive swine may be chronic shedders for Brucella and Leptospira via urine and other body fluids.

Venereal transmission from carrier boars and sows may play a role in maintenance of the disease (Bharti et al., 2003).

It can be concluded that serological assays concerning brucellosis and leptospirosis verifies direct occupational exposure for high risk group manipulating carrier swine or their pollutant conditions. Also, this study reflect the need of public health worry by Egyptian veterinary authorities' toward swine on such condition that constitutes spots for spread out epidemics.

\section{REFERENCES}

Al Dahouk S.; Tomaso, H.; Nockler, K.; Neubauer, H. and Frangoulidis, D. (2003): Laboratory-based diagnosis of brucellosis - a review of the literature. Part $\Pi$ : serological test for brucellosis. Clin. Lab. 49: 577-589.

Alton, G.G.; Jones, L.M.; Angus, R.D. and Verger, J.M. (1988): Technigueds for the brucellosis laboratory. Institut National de Recherche Agronomigue, Paris

Baba, M.M.; Sarkindared, S.E. and Brisibe, F. (2001): Serological evidence of brucellosis among predisposed patients with pyrexia of unknown origin in the north eastern Nigeria. Cent. Eur. J. Public Health. 9: 158-161.

Benschop, J.; Heuer, C.; Jaros, P.; Collins-Emerson, J.; Midwinter, A. and Wilson, P. (2009): Seroprevalence of leptospirosis in workers at a New Zealand slaughterhouse. $\mathrm{N} Z$ Med. J.; 122(1307): 39-47.

Bharti, A.R.; Nally, J.E.; Ricaldi, J.N.; Matthias, M.A.; Diaz, M.M.; Lovett, M.A.; Levett, P.N.; Gilman, R.H.; Willig, M.R.; Gotuzzo, E. and Vinetz, J.M. (2003): "Leptospirosis: a zoonotic disease of global importance". Indian J. Med. Sci. 57: 181-186. 
Birnbaum, N.; Barr, S.C.; Center, S.A.; Schermerhorn, J.; Randolph, J.F. and Simpson, K.W. (1998): Naturally acquired leptospirosis in 36 dogs: Serologic and clinicopathological features. J. Sm. Anim. Pract. 39: 231.

Burriel, A.R.; Varoudis, L. and Alexopoulos, C. (2003): Serological evidence of Brucella species and Leptospira interrogans serovars in Greek swine herds. J Swine Health Prod. 11(4): 186-189.

COLE, J.R.; Sulzer, Cr. and Pursell, AR. (1973): Improved microtechnique for the leptospiral microscopic agglutination test. Appl. Microbiol., 25: 976.

De. Azevedo, S.S.; Soto, F.R.M.; Morais, Z.M.D.E.; Pinheiro, S.R.; Batista, C.S.A.; Vuaden, E. and Vasconcellos, S.A. (2008): The effects of the leptospiral infection on reproductive performance in sows. Vet. Arhiv 78: 13-21.

De Lange, J.F.; Gummow, B.; Turner, G.V. and Redmann, A.R. (1987): The isolation of Leptospira interrogans serovar Pomona and related serological findings associated with a mixed farming unit in the Transvaal. Onderstepoort J. Vet. Res. 54: 119-121.

Ellis, W.A. (1999): Leptospirosis. In: Diseases of Swine. (Straw, B.E., S. D'allaire, W.L. Mengeling, D.J. Taylor, Eds). $8^{\text {th }}$ ed. Lowa State Press. Ames. Pp. 483-493.

Faine, S. (1994): Leptospira and leptospirosis (London: CRC Press)

Faine, S.; Adler, B.; Bolin, C. and Perolat, P. (1999): Leptospira and leptospirosis, $3^{\text {rd }}$ ed., MediSci. Melbourne. P 272.

Hadad, E.; Pirogovsky, A.; Bartal, C.; Gilad, J.; Barnea, A. and Yitzhaki, S. (2006): An outbreak of leptospirosis among Israeli troops near the Jordan River. Am. J. Trop. Med. Hyg.; 74(1): 127-131.

Hathaway, S.C. and Little, T.W.A. (1981): Prevalence and clinical significance of leptospiral antibodies in pigs in England. Vet. Rec. 108, 224-228.

Levett,P.N.(2001):"Leptospirosis".Clin.Microbiol.Rev . 14: 296-326.

Maichomo, M.W.; McDermaott, J.J.; Ariml, S.M. and Gathura, P.B. (1998): Assessment of the RoseBengal plate test for the diagnosis of human brucellosis in health facilities in Narok district, Kenya. East Afr. Med. J. 75:219-222.

Mousing, J.; Christensen, J.; Haugegaard, J.; Schirmer, A.L. and Friis, N.F. (1995): A seroepidemiological survey of Leptospira bratislava infections in Danish sow herds. Prev. Vet. Med. 23, 201-213.

Mudaliar, S.; Bhore, A. and Pandit, D. (2003): Detection of antibodies to Brucella abortus in animal handlers. Indian J. Med. Sci.57: 181186.

Mutanda, L.N. (1998): Selected laboratory tests in febrile patients in Kampala, Uganda. East Afr. Med. J. 75: 68-72.
Nicolet, P. (1982): Diagnosis and vaccination for the control of brucellosis in the near east. FAOpublication, Rome.

Omer, M.K.; Assefaw, T.E.; Skjerve, T.; Tekleghiorghis, A. and Woldehiwet, Z. (2002): Prevalence of antibodies to Brucella sp. and risk factors related to high-risk occupational groups in Eritrea. Epidemiol. Infect. 129: 8591.

Pappas, G.; Papadimitriou, P.; Akritidis, N.; Christou, L. and Tsianos, E.V. (2006): The new global map of human brucellosis. Lancet Infect. Dis. 6: 91-99.

Rose, JE. and Roepke, MH. (1957): An acidified antigen for detection of nonspecific reactions in the plate-agglutination test for bovine brucellosis. Am. J. Vet. Res. Jul; 18(68): 550555.

Schelling, E.; Diguimbaye, C.; Daoud, S.; Nicolet, J.; Boerlin, P.; Tanner, M. and Zinsstag, J. (2003): Brucellosis and Q-fever seroprevalence of nomadic pastoralists and their livestock in Chad. Prev. Vet. Med. 61: 279-293.

Shimshony Arnon, D.V.M. (2009): Porcine Brucellosis: another Common zoonoses in Pigs.

Slack, A.T.; Khairani-Bejo, S.; Symonds, M.L.; Dohnt, M.F.; Galloway, R.L.; Steigerwalt, A.G.; Bahaman, A.R.; Craig, S. and Harrower, B.J. (2008): Leptospira kmetyi sp. Nov., isolated from an environmental source in Malaysia. Int. J. Syst. Evol. Microbiol. Int.30.

Smits, H.L. and Cutler S.J. (2004):Contributions of biotechnology to the control and prevention of brucellosis in Africa. Afr. J.Biotechnol. 3: 631.

Tiwari, RR. (2008): Occupational health hazards in sewage and sanitary workers. Indian $J$. Occupational Environmen Med. 12(3):112-5.

Ullmann, L.S. and Langoni, H. (2011): Interactions between environment, wild animals and human leptospirosis. J. Venom. Anim. Toxins incl. Trop. Dis. 17: 119-129.

Van Til, L.D. and Dohoo, R. (1991): A serological survey of leptosirosis in prince Edward island swine herds and its association with infertility. Can. J. Vet Res. 55: 352-355.

WHO (1998): The MZCP Report on the Third Workshop on Human and Animal Brucellosis Epideniological Surveillance in the MZCP Countries Damascus, Syriab Arab Republic, 45 May 1998 (1-47).

Young, E.J. (1995): An overview of human brucellosis. Clin. Infect. Dis. 21: 283-289.

Zaki, R. (1948): Brucella infection among ewes, camels and pigs in Egypt. J. Comp. Path. 58: 145-151.

Zakład Chorób Swiń, Państwowy Instytut Weterynaryjny-Państwowy Instytut Badawczy w Puławach. (2011): Leptospirosis--current problems. wasinski@piwet.pulawy.plPrzegl Epidemiol.; 65(3): 471-6. 


\section{المخاطر الصحية لأهم الأمراض المشتركة كالبروسيلوزس والليتوسبيروزس فى الخنازير المصرية والمخالطين لها}

\section{أثرف بركات ، السبي رضوان ، سيلفيا /حد}

تربى الخنازير فى مصر دون تفتيش صحى بيطرى فالخنازير بطيعتها تتعرض لكثير من الكير المسببات الممرضة نتيجة رعيها على المخلفات الادمية.

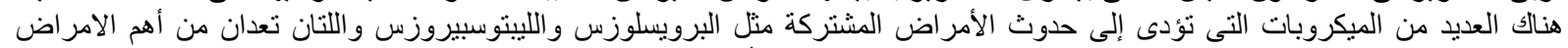

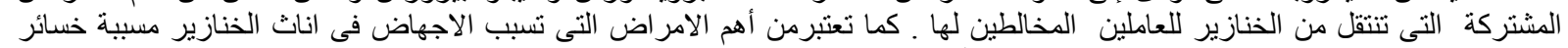

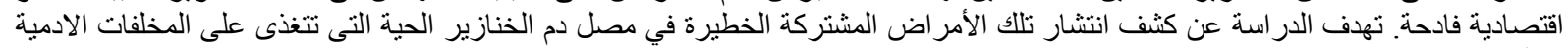

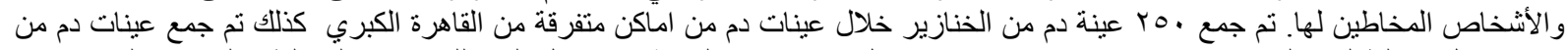

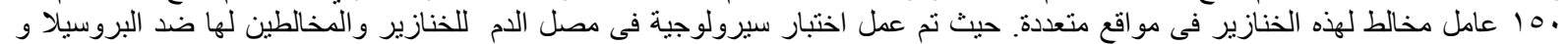

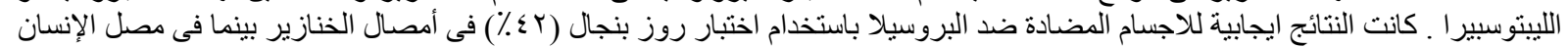

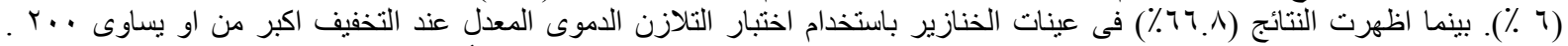

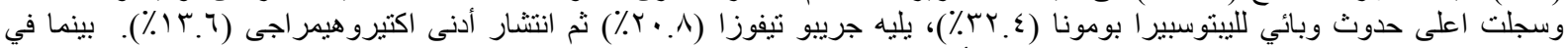

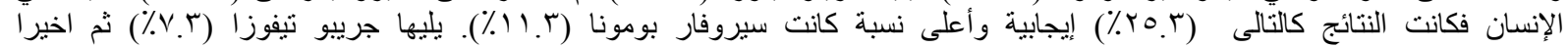

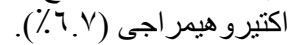

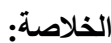

يعتبر مرض البروسيلوزس والليبتوسبيروزس من اهم الامراض المشتركة وكانت نسب الاصابة فى الخنازير النى تتخذى عل المخلفات الادمية ايجابية وتمثل مصدر لانتشار الامر اضل للعمال المخالطين من خلال الحيو النات الحاملة للامر اض. لاض. 